\title{
Trophic niche comparison between two predators in northern Rio de Janeiro State, Brazil: a stable isotopes approach
}

\author{
Ana Paula Madeira Di Beneditto ${ }^{1,3}$, Carlos Eduardo Rezende ${ }^{1}$, \\ Plínio Barbosa Camargo² \& Helena Amaral Kehrig ${ }^{1}$ \\ ${ }^{1}$ Laboratório de Ciências Ambientais, Centro de Biociências e Biotecnologia - CBB, \\ Universidade Estadual do Norte Fluminense - UENF, CEP 28013-602, Campos dos Goytacazes, RJ, Brazil \\ ${ }^{2}$ Laboratório de Ecologia Isotópica, Centro de Energia Nuclear na Agricultura - CENA, \\ Universidade de São Paulo - USP, CEP 13416-100, Piracicaba, SP, Brazil \\ ${ }^{3}$ Corresponding author: Ana Paula Madeira Di Beneditto, e-mail: anapaula@uenf.br
}

DI BENEDITTO, A.P.M, REZENDE, C.E., CAMARGO, P.B. \& KEHRIG, H.A. Trophic niche comparison between two predators in northern Rio de Janeiro State, Brazil: a stable isotopes approach. Biota Neotrop.13(3): http://www.biotaneotropica.org.br/v13n3/en/abstract?article+bn00613032013

\begin{abstract}
The trophic niche of the sympatric predators Pontoporia blainvillei (franciscana dolphin) and Trichiurus lepturus (ribbonfish) was compared by stable isotope $\left(\delta^{15} \mathrm{~N}\right.$ and $\left.\delta^{13} \mathrm{C}\right)$ ratios in hepatic and muscular tissues to understand how they co-exist in the northern Rio de Janeiro State (21 ${ }^{\circ} 30^{\prime} \mathrm{S}-22^{\circ} 15$ 'S), south-eastern Brazil. Dolphin specimens were incidentally captured through commercial gillnet fisheries, while fish specimens were the target of these fisheries. The predators had similar $\delta^{15} \mathrm{~N}$ values in the liver (P. blainvillei: $14.6 \pm 1.0 \%$; T. lepturus: $14.4 \pm 0.6 \%$ ), which indicates similar trophic position in the recent food intake. However, P. blainvillei showed lighter $\delta^{15} \mathrm{~N}$ values in muscle $(13.8 \pm 1.0 \%$ ) than T. lepturus $(15.0 \pm 0.4 \%$ ), revealing differences in the long term diet that could be related with the prey size ingested. The $\delta^{13} \mathrm{C}$ signatures showed a preferential inshore and benthic food chain for P. blainvillei (liver: $-15.2 \pm 0.6 \%$; muscle: $-16.0 \pm 0.5 \%$ ) and a more offshore and pelagic food chain for T. lepturus (liver: $-17.2 \pm 0.6 \%$; muscle: $-16.8 \pm 0.3 \%$ ). The isotopic variances of liver and muscle revealed a broader niche width to $P$. blainvillei in relation to T. lepturus, with a greater use of available food resources in coastal waters. In the area of study, the differences in habitat use and exploitation of food resources are favoring the predators' coexistence.
\end{abstract}

Keywords: trophic niche, marine vertebrates, stable isotopes, Rio de Janeiro, Southwest Atlantic.

DI BENEDITTO, A.P.M., REZENDE, C.E., CAMARGO, P.B. \& KEHRIG, H.A. Comparação do nicho trófico entre dois predadores no norte do estado do Rio de Janeiro, Brasil: uma abordagem de isótopos estáveis. Biota Neotrop. 13(3): http://www.biotaneotropica.org.br/v13n3/pt/abstract?article+bn00613032013

Resumo: O nicho trófico dos predadores simpátricos Pontoporia blainvillei (golfinho franciscana) e Trichiurus lepturus (peixe-espada) foi comparado através de razões de isótopos estáveis $\left(\delta^{15} \mathrm{~N}\right.$ and $\left.\delta^{13} \mathrm{C}\right)$ nos tecidos hepático e muscular para compreender como eles coexistem no norte do Estado do Rio de Janeiro (2130'S-22 ${ }^{\circ} 15^{\prime} \mathrm{S}$ ), sudeste do Brasil. Os espécimes do golfinho foram capturados acidentalmente em pescarias comerciais com rede de espera, enquanto os espécimes do peixe foram alvo dessas pescarias. Os predadores apresentaram valores similares de $\delta^{15} \mathrm{~N}$ no fígado (P. blainvillei: $14.6 \pm 1.0$; T. lepturus: $14.4 \pm 0.6$ ), o que indica posição trófica semelhante quanto à ingestão alimentar recente. No entanto, $P$. blainvillei apresentou valores mais leves de $\delta^{15} \mathrm{~N}$ no músculo $(13.8 \pm 1.0)$ em relação a T. lepturus $(15.0 \pm 0.4)$, revelando diferenças na dieta de longo prazo que podem estar relacionadas ao tamanho das presas ingeridas. As assinaturas de $\delta^{13} \mathrm{C}$ indicaram uma cadeia alimentar preferencialmente costeira e bentônica para $P$. blainvillei (fígado: $-15.2 \pm 0.6$; músculo: $-16.0 \pm 0.5$ ) e uma cadeia alimentar mais oceânica e pelágica para T. lepturus (fígado: $-17.2 \pm 0.6$; músculo: $-16.8 \pm 0.3$ ). As variâncias isotópicas do fígado e do músculo revelaram uma maior amplitude de nicho para P. blainvillei em relação a T. lepturus, com maior aproveitamento dos recursos alimentares disponíveis em águas costeiras. $\mathrm{Na}$ área de estudo, as diferenças no uso do habitat e na exploração de recursos alimentares estão favorecendo a coexistência dos predadores.

Palavras-chave: nicho trófico, vertebrados marinhos, isótopos estáveis, Rio de Janeiro, Atlântico Sul Ocidental. 


\section{Introduction}

Species that require similar feeding resources and co-exist in the same habitat tend to minimize food competition by using different physical areas or preying on different species (Pimm 2002). The target species of this study are two predators that co-exist in coastal waters of the Southwest Atlantic Ocean: franciscana dolphin Pontoporia blainvillei (Gervais \& D'Orbigny 1844) and ribbonfish Trichuirus lepturus (Linnaeus 1758). The species P. blainvillei is the most vulnerable dolphin along the southwest Atlantic Ocean due to their encounters with gillnet fisheries, and their populations are considered to be decreasing (International... 2012). Its distribution is restricted to waters up to $30 \mathrm{~m}$ depth, between $19{ }^{\circ} \mathrm{S}$ to $38^{\circ} \mathrm{S}$ (Crespo et al. 1998, Di Beneditto 2003). The species T. lepturus may be found along tropical and sub-tropical latitudes and it is an important fishery resource worldwide. Juvenile and subadult specimens are related to estuarine and coastal waters, while adult specimens move along the continental shelf widely, reaching the continental slope and oceanic waters (Martins et al. 2005, Froese \& Pauly 2012).

Studies on stomach content analysis indicated that $P$. blainvillei feeds preferentially on fishes and squids up to $10 \mathrm{~cm}$ length (Di Beneditto \& Ramos 2001, Danilewicz et al. 2002). In contrast, the feeding habit of T. lepturus changes during its ontogeny, being zooplanktivorous at juvenile stage $(5-30 \mathrm{~cm}$ length) and becoming a carnivore when adult (>100 cm length), feeding mainly on fishes (Martins et al. 2005). A previous comparison about the food preference of these predators in northern Rio de Janeiro State, southeastern Brazil, through stomach content analysis, showed a feeding overlap in which $60 \%$ of total food resources consumed were shared between them (Bittar \& Di Beneditto 2009).

The stomach content analysis of dead vertebrates is commonly used to identify the preferential prey and their quantitative contribution to diet (e.g. Ohizumi et al. 2003, Di Beneditto \& Ramos 2001, Bittar et al. 2008). Indeed, this is the more efficient method for the taxonomic recognition and size estimates of prey ingested by aquatic predators. However, stomach content analysis usually indicates the last food intake, but not the dietary input over time (food assimilation). Thus, complementary analysis with other diet markers such as stable isotopes can provide additional information about feeding preference and trophic niche in the ecosystem (Di Beneditto et al. 2011).

Stable isotope measurements have provided useful data on marine vertebrates' trophic ecology, indicating the food assimilated from feeding activities and food sources (e.g. Das et al. 2000, Hobson et al. 2002; Di Beneditto et al. 2011, 2012). In general, stable isotope ratios of a consumer are related to those of their prey and consumers that occupy the same trophic position have similar isotopic measurements (Renaud et al. 2011, Di Beneditto et al. 2011). In trophic ecology approaches, stable isotope of nitrogen $\left(\delta^{15} \mathrm{~N}\right)$ has been mainly used to recognize different trophic levels and food assimilation over time, while carbon $\left(\delta^{13} \mathrm{C}\right)$ indicates different dietary-based carbon sources (e.g. inshore vs. offshore, pelagic vs. benthic or aquatic vs. terrestrial) (DeNiro \& Epstein 1978, Peterson \& Fry 1987, Fry 2008). Additionally, the concept of isotopic niche, gathering $\delta^{15} \mathrm{~N}$ and $\delta^{13} \mathrm{C}$ measurements, has been used to better understand species' trophic niche width and competition or coexistence among species (Bearhop et al. 2004, Newsome et al. 2007, Franco-Trecu et al. 2012).

The aim of this study is to describe the trophic niche of $P$. blainvillei and T. lepturus in the coastal waters of northern Rio de Janeiro State using stable isotope analyses in hepatic and muscular tissues to understand how they co-exist in the study area.

\section{Material and methods}

\section{Sampling}

The area of study is the northern Rio de Janeiro State $\left(21^{\circ} 30^{\prime} \mathrm{S}-22^{\circ} 15^{\prime} \mathrm{S}\right)$ (Figure 1). Dolphin specimens were incidentally captured through commercial gillnet fisheries while fish specimens were the target of these fisheries. In this area the gillnet fisheries are conducted along the continental shelf, whose slope is located around $100 \mathrm{~m}$ depth. The specimens were captured in waters from 2 to $56 \mathrm{~km}$ from the coastline, in depths varying from 10 to $50 \mathrm{~m}$. Only adult fish ( $>100 \mathrm{~cm}$ length) were considered for this study due to their potential to be a trophic competitor of P. blainvillei (Bittar \& Di Beneditto 2009). A sub-sample from the back dorso-lateral muscle and the liver (entire for T. lepturus and final portion of the largest lobe for P. blainvillei) were removed. All tissue samples were freeze-dried and homogenized with a mortar and pestle for stable isotope analyses.

\section{Stable isotope analysis}

Stable isotope ratios were determined in dry hepatic and muscular tissue samples, without lipid-extraction, using a Thermo QuestFinnigan Delta Plus isotope ratio mass spectrometer (FinniganMAT) interfaced with an Elemental Analyzer (Carlo Erba). Pee Dee beleminite carbonate and atmospheric nitrogen were used as standard values for carbon and nitrogen analyses, respectively. The analytical precision was \pm 0.1 for $\delta^{13} \mathrm{C}$ and \pm 0.2 for $\delta^{15} \mathrm{~N}$ (triplicate samples of every fifth sample).

The tissues samples were not lipid-extracted, which could have influenced $\delta^{13} \mathrm{C}$ results. Kiljunen et al. (2006) and Post et al. (2007) stated that a $\mathrm{C}: \mathrm{N}$ ratio less than 3.5 indicates that the tissue contains zero extractable lipid. The mean $\mathrm{C}: \mathrm{N}$ ratios of the muscle samples, by weight from elemental composition, were less than 3.5 and indicated a low lipid content. In this sense, the lipid-extraction was not considered a restriction on muscle $\delta^{13} \mathrm{C}$ values interpretation. Meanwhile, hepatic tissue usually has high lipid content and should be lipid-corrected (Sweeting et al. 2006). We applied the lipid-normalizing $\delta^{13} \mathrm{C}$ to liver samples, as proposed by Logan et al. $(2008)$ : $\delta^{13} \mathrm{C}^{\prime}=0.967 \times$ $\delta^{13} \mathrm{C}+0.861$

\section{Data analysis}

The assumptions of normality and homoscedasticity were assessed through Shapiro-Wilk and Levene tests, respectively. The data fit a normal distribution, but the homoscedasticity was not verified in all cases. In this sense, Welch $t$-test for non-homogeneous samples was applied to verify the diet and feeding ground overlaps between P. blainvillei and T. lepturus considering stable isotopes measurements in hepatic and muscular tissues. The trophic niche width of predators was compared through the isotopic variance of liver and muscle, using a simple variance ratio test ( $F$-test), as described in Bearhop et al. (2004). The statistical analysis was performed using Statistica 10.0 for Windows (StatSoft, Inc 1984-2011, USA) and R 2.12.2 for Windows (R Development Core Team 2011). A $p$ value equal or less than 0.05 was chosen to indicate statistical significance.

\section{Results and Discussion}

The $\delta^{15} \mathrm{~N}$ values in the liver ranged from 13.3 to $16.9 \%$ to P. blainvillei (mean: $14.6 \pm 1.0 \%$ ), and 13.7 to $15.5 \%$ to T. lepturus (mean: $14.4 \pm 0.6 \%$ ) (Figure 2). No significant difference was detected between predators $(t=-1.097 ; p=0.279)$. However, the $\delta^{15} \mathrm{~N}$ values in muscular tissue of $P$. blainvillei (11.2 to $15.6 \%$; mean: $13.8 \pm 1.0 \%$ ) were significantly lighter $(t=3.986 ; p<0.001)$ than in T. lepturus (14.0 to $15.5 \%$; mean: $15.0 \pm 0.4 \%$ ) (Figure 2). 


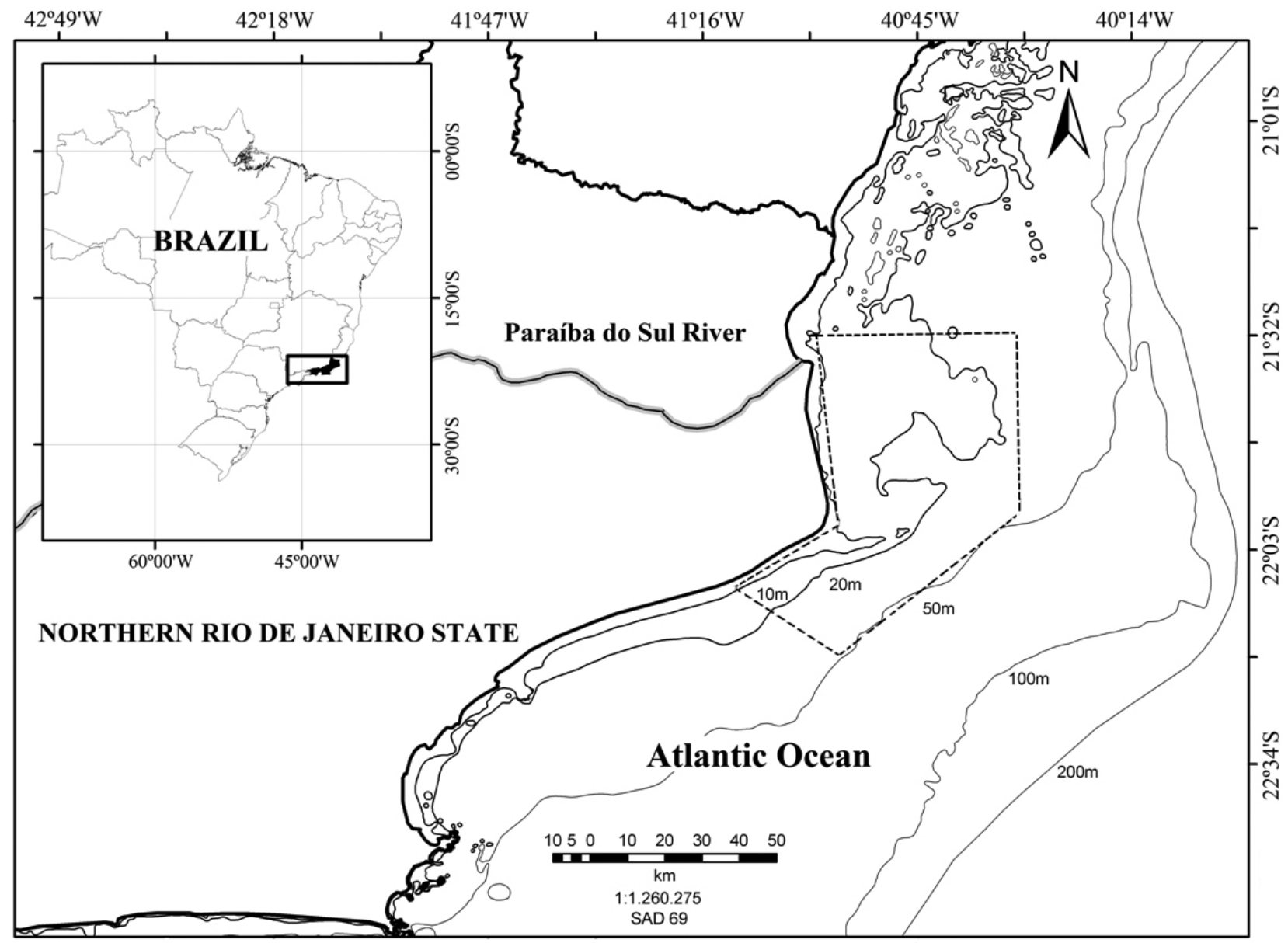

Figure 1. Northern Rio de Janeiro State, south-eastern Brazil, where Pontoporia blainvillei and Trichiurus lepturus specimens were captured (dotted area).

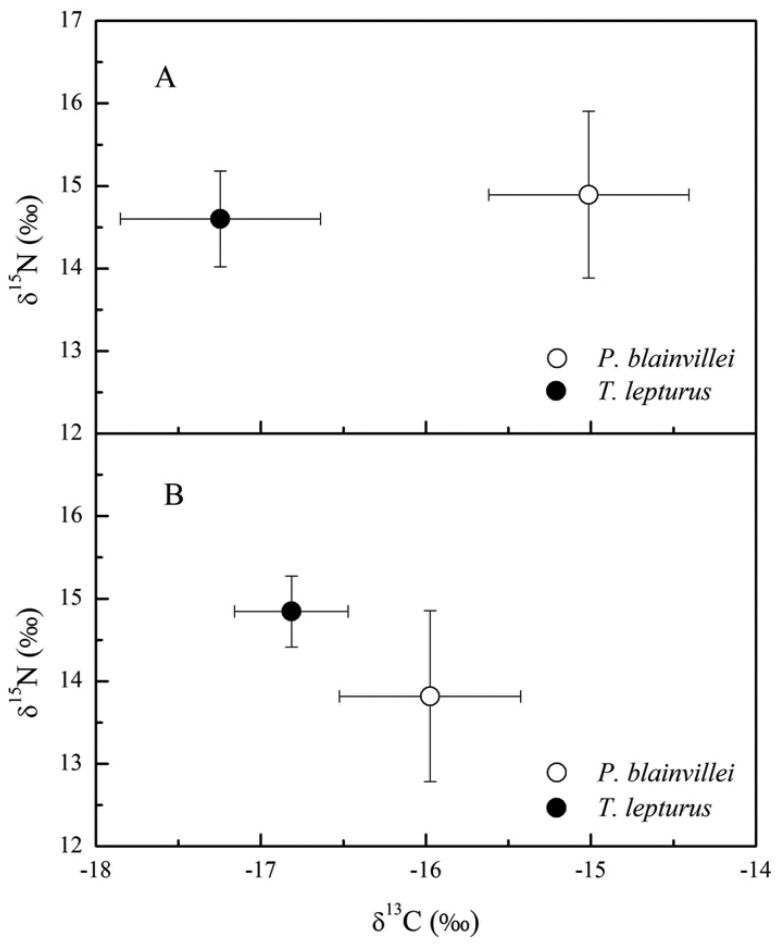

Figure 2. Stable isotopes $\left(\delta^{15} \mathrm{~N}\right.$ and $\left.\delta^{13} \mathrm{C}\right)$ values in the liver (A) and muscle (B) of Pontoporia blainvillei and Trichiurus lepturus specimens.
Comparisons of $\delta^{15} \mathrm{~N}$ signatures in different tissues allow food ingestion evaluation in different periods of time, as days, weeks or months (Hobson et al. 1996, Das et al. 2000, Fry 2008). Considering hepatic and muscular tissues, the turnover rate is faster in the former due to differences in metabolic activity (Tieszen et al. 1983, Hesslein et al. 1993). From this perspective, it is possible to suggest that $\delta^{15} \mathrm{~N}$ signatures in the liver are normally derived by more recent food ingestion (e.g., days or weeks) than in the muscle (e.g. months).

The feeding ground (and diet) overlap between these predators in the area of study should occur when adult specimens of T. lepturus move along shallower waters. At this time, P. blainvillei (with a restrict area of distribution in the inner continental shelf) and T. lepturus (with a wide area of distribution along the entire continental shelf) share the available food resources, that can include the same prey species with similar size. Since the analyzed specimens were captured in the inner continental shelf (see Material and Methods), the recent feeding events (measured by $\delta^{15} \mathrm{~N}$ signatures in the liver) were probably similar, as well as the predators' trophic level in this feeding ground. This could explain the similar results of hepatic $\delta^{15} \mathrm{~N}$ for T. lepturus and $P$. blainvillei specimens.

On the other hand, the $\delta^{15} \mathrm{~N}$ ratios in muscle of P. blainvillei specimens were lighter than in T. lepturus specimens, showing differences between predators when considering the trophic level in a long-term diet. According to Bittar \& Di Beneditto (2009), the predators are sharing $60 \%$ of the total food resources ingested, but the average prey size consumed by T. lepturus is twice greater than P. blainvillei's. In general, small size specimens of a given species 
are less $\delta^{15} \mathrm{~N}$ enriched than the large ones (Jennings et al. 2002), and this condition could explain the muscle $\delta^{15} \mathrm{~N}$ differences between predators.

Stable carbon isotope was specifically grouped in both tissues (Figure 2). In P. blainvillei specimens the values ranged from -15.6 to $-13.4 \%$ (mean: $-15.2 \pm 0.6 \%$ ) in hepatic tissue and -17.1 to $-14.9 \%$ (mean: $-16.0 \pm 0.5 \%$ ) in muscular tissue, while in T. lepturus specimens the values ranged from -18.4 to $-16.5 \%$ (mean: -17.2 $\pm 0.6 \%$ ) and -17.8 to $-16.3 \%$ (mean: $-16.8 \pm 0.3 \%$ ) in liver and muscle, respectively (Figure 2). In both tissues, the values of $\delta^{13} \mathrm{C}$ for T. lepturus were significantly lighter than in P. blainvillei (liver: $t=-11,01 ; p<0.001$; muscle: $t=-5,692 ; p<0.001)$.

Differences in $\delta^{13} \mathrm{C}$ signatures reflect differences in habitat use between these predators. The $\delta^{13} \mathrm{C}$ signatures are usually applied to distinguish different dietary-based carbon sources: benthic and inshore trophic chains are usually enriched in $\delta^{13} \mathrm{C}$ compared to pelagic and offshore ones (DeNiro \& Epstein 1978, Hobson 1999, Lesage et al. 2001, Fry 2008). Thus, $\delta^{13} \mathrm{C}$ signatures showed a preferential inshore and benthic food chain for P. blainvillei and a more offshore and pelagic food chain for T. lepturus.

In $P$. blainvillei, the variances in $\delta^{15} \mathrm{~N}$ values (liver: 1.02 ; muscle: 1.10$)$ were significantly greater $(F=3.01 ; p=0.026)$ than in T. lepturus (liver: 0.34; muscle: 0.17 ), reflecting a broader niche width to the dolphin. Considering the pool of ingested prey species by each predator, this result indicates that the number of prey species that have importance in the diet of P. blainvillei is greater than in T. lepturus, corroborating the prey's index of relative importance analysis done in Bittar \& Di Beneditto (2009).

The variances in $\delta^{13} \mathrm{C}$ values in hepatic tissue were similar between predators ( $P$. blainvillei: $0.38 ;$ T. lepturus: $0.35 ; F=$ $1.06 ; p=0.884)$. This can indicate similar trend regarding feeding grounds used by both predators in recent feeding events, when they are sharing the coastal waters along the inner continental shelf and probably the food resources, as discussed above. The variances in muscle $\delta^{13} \mathrm{C}$ of $P$. blainvillei (0.30) was greater than T. lepturus (0.12), but with no significant difference $(F=2.50 ; p=0.061)$. Although demersal feeding ground seems to be more important to P. blainvillei than pelagic ones, as shown by $\delta^{13} \mathrm{C}$ values (Figure 2), this predator explores both sites to capture its preferred prey (Di Beneditto \& Ramos 2001). On the other hand, T. lepturus is a typical pelagic predator (Bittar et al. 2008). These characteristics would lead to differences in the variances considering the muscular $\delta^{13} \mathrm{C}$ values.

In the area of study, some previous investigations described in details the feeding habits of both predators through stomach content analysis. Both pelagic (e.g., Doryteuthis spp, Anchoa filifera, Pellona harroweri and Chirocentrodon bleekerianus) and demersal species (Stellifer spp, Isopisthus parvipinnis and Cynoscion jameicensis) were identified as preferential prey of P. blainvillei (Di Beneditto \& Ramos 2001). Regarding T. lepturus, only pelagic species were among the most consumed prey (e.g., T. lepturus - juvenile specimens, P. harroweri, C. bleekerianus and Lycengraulis grossidens and Doryteuthis spp) (Bittar et al. 2008, 2012). Comparing the previous stomach content analysis with the stable carbon isotope signatures measured in the present study, we can argue that demersal prey species are more important for $P$. blainvillei than previously thought. This feeding strategy can reduce the trophic competition between P. blainvillei and T. lepturus (and other pelagic predators) in coastal areas. Additionally, the trophic niche width of P. blainvillei indicates its great ability in using the available food resources, compensating its limits regarding the distributional area and allowing the coexistence with trophic competitors, as T. lepturus.

\section{Acknowledgments}

We thank fishermen from Atafona Harbour and Silvana Ribeiro Gomes, who provided us with franciscana dolphin and ribbonfish specimens. APM Di Beneditto was supported by Conselho Nacional de Desenvolvimento Científico e Tecnológico - CNPq (Proc. 300241/2009-7 and 403735/2012-2) and Fundação Carlos Chagas Filho de Amparo a Pesquisa do Estado do Rio de Janeiro - FAPERJ (Proc. E-26/102.915/2011). CE Rezende was supported by CNPq (Proc. 304615/2010-2) and FAPERJ (Proc. E-26/102.945/2011). This work was partially supported by CNPq INCT Material Transference from the Continent to the Ocean (Proc. 573.601/2008-9). Franciscana dolphin's research permit was provided by the Brazilian Government/ Instituto Brasileiro do Meio Ambiente e dos Recursos Naturais Renováveis (Permit nº 012-02/CMA/IBAMA).

\section{References}

BEARHOP, S., ADAMS, C.E., WALDRON, S., FULLER, R.A. \& MacLEOD, H. 2004. Determining trophic niche width: a novel approach using stable isotope analysis. J. Anim. Ecol. 73:1007-1012. http://dx.doi. org/10.1111/j.0021-8790.2004.00861.x

BITTAR, V.T., CASTELLO, B.F.L. \& DI BENEDITTO, A.P.M. 2008. Hábito alimentar do peixe-espada adulto, Trichiurus lepturus, na costa norte do Rio de Janeiro, sudeste do Brasil. Biotemas 21:83-90. http://dx.doi. org/10.5007/2175-7925.2008v21n2p83

BITTAR, V.T. \& DI BENEDITTO, A.P.M. 2009. Diet and potential feeding overlap between Trichiurus lepturus (Osteichthyes, Perciformes) and Pontoporia blainvillei (Mammalia, Cetacea) in northern Rio de Janeiro, Brazil. Zoologia 26:374-378. http://dx.doi.org/10.1590/S198446702009000200023

BITTAR, V.T., AWABDI, D.R., TONINI, W.C.T., VIDAL JÚNIOR, M.V. \& DI BENEDITTO, A.P.M. 2012. Feeding preference of adult females of ribbonfish Trichiurus lepturus L. 1758 through prey proximatecomposition and caloric values. Neot. Ichth. 10:193-203.

CRESPO, E.A., HARRIS, G. \& GONZÁLEZ, R. 1998. Group size and distributional range of the franciscana, Pontoporia blainvillei. Mar. Mamm. Sci. 14:845-849. http://dx.doi.org/10.1111/j.1748-7692.1998. tb00768.x

DANILEWICZ, D., ROSAS, F., BASTIDA, R., MARIJO, J., MUELBERT, M., RODRÍGUEZ, D., LAILSON-BRITO JUNIOR, J., RUOPOLLO, V., RAMOS, R., BASSOI, M., OTT, P.H., CAON, G., ROCHA, A.M., CATÃO-DIAS, J.L. \& SECCHI, E.R. 2002. Report of the Working Group on Biology and Ecology. LAJAM 1:25-42. http://dx.doi.org/10.5597/ lajam00005

DAS, K., LEPOINT, G., LOIZEAU, V., DEBACKER, V., DAUBY, P. \& BOUQUEGNEAU, J.M. 2000. Tuna and dolphin associations in the North-East Atlantic: evidence of different ecological niches from stable isotope and heavy metal measurements. Mar. Pollut. Bull. 40:102109. http://dx.doi.org/10.1016/S0025-326X(99)00178-2

DENIRO, M.J. \& EPSTEIN, S. 1978. Influence of diet on the distribution of carbon isotopes in animals. Geochim. Cosmochin. Ac. 42:495-506. http://dx.doi.org/10.1016/0016-7037(78)90199-0

DI BENEDITTO, A.P.M. 2003. Interactions between gillnet fisheries and small cetaceans in northern Rio de Janeiro, Brazil: 2001-2002. LAJAM 2:79-86. http://dx.doi.org/10.5597/lajam00035

DI BENEDITTO, A.P.M. \& RAMOS, R.M.A. 2001. Biology and conservation of the franciscana (Pontoporia blainvillei) in the north of Rio de Janeiro, Brazil. J. Cetacean Res. Manag. 2:185-192.

DI BENEDITTO, A.P.M., SOUZA, C.M.M., KEHRIG, H.A. \& REZENDE, C.E. 2011. Use of multiple tools to assess the feeding preference of coastal dolphins. Mar. Biol. 158:2209-2217. http://dx.doi.org/10.1007/ s00227-011-1726-3 
DI BENEDITTO, A.P.M., BITTAR, V.T., CAMARGO, P.B., REZENDE C.E. \& KEHRIG, H.A. 2012. Mercury and nitrogen isotope in a marine species from a tropical coastal food web. Arch. Environ. Con. Tox. 44:264-271. PMid:21858737. http://dx.doi.org/10.1007/s00244-011-9701-z

FRANCO-TRECU, V., AURIOLES-GAMBOA, ARIM, M. \& LIMA, M. 2012. Prepartum and postpartum trophic segregation between sympatrically breeding female Arctocephalus australis and Otaria flavescens. J. Mammal 93:514-521. http://dx.doi.org/10.1644/11MAMM-A-174.1

FROESE, R. \& PAULY, D. 2012. FishBase. World Wide Web electronic publication. www.fishbase.org (último acesso em 08/2012).

FRY, B. 2008. Stable isotope ecology. Springer Science Business Media, New York.

HESSLEIN, R.H., HALLARD, K.A. \& RAMLAL, P. 1993. Replacement of sulphur, carbon, and nitrogen tissue of growing broad whitefish (Coregonus nasus) in response to a change in diet traced by $\mathrm{d} 34 \mathrm{~S}$, d13C, and d15N. Can. J. Fish. Aquat. Sci. 50:2071-2076. http://dx.doi. org/10.1139/f93-230

HOBSON, K.A. 1999. Tracing origins and migration of wildlife using stable isotopes: a review. Oecologia 120:314-326. http://dx.doi. org/10.1007/s004420050865

HOBSON, K.A., SCHELL, D., RENOUF, D. \& NOSEWORTHY, E. 1996. Stable-carbon and nitrogen isotopic fractionation between diet and tissues of captive seals: implications for dietary reconstructions involving marine mammals. Can. J. Fish. Aquat. Sci. 53:528-533. http://dx.doi. org/10.1139/f95-209

HOBSON, K.A., FISK, A., KARNOVSKY, N., HOLST, M., GAGNON, J.M. \& FORTIER, M. 2002. A stable isotope (d13C, d15N) model for the North Water food web: implications for evaluating trophodynamics and the flow of energy and contaminants. Deep-Sea Res. II 49:5131-5150. http://dx.doi.org/10.1016/S0967-0645(02)00182-0

INTERNATIONAL UNION FOR CONSERVATION OF NATURE - IUCN 2012. IUCN Red List of Threatened Species. Version 2011.2. Available at www.iucnredlist.org. Accessed in 05 November 2012.

JENNINGS, S., PINNEGAR, J.K., NICHOLAS, V.C. \& WARR, K.J. 2002. Linking size-based and trophic analyses of benthic community structure. Mar. Ecol-Prog. Ser. 226:77-85. http://dx.doi.org/10.3354/meps226077

KILJUNEN, M., GREY, J., SINISALO, T., HARROD, C., IMMONEN, H. \& JONES, RI. 2006. A revised model for lipid-normalizing $\delta^{13} \mathrm{C}$ values from aquatic organisms, with implications for isotope mixing models. J. Appl. Ecol. 43:1213-1222. http://dx.doi.org/10.1111/j.1365-2664.2006.01224.x
LESAGE, V., HAMMIL, M.O. \& KOVACS, K.M. 2001. Marine mammals and the community structure of the Estuary and Gulf of St Lawrence, Canada: evidence from stable isotope analysis. Mar. Ecol-Prog. Ser. 210:203-221. http://dx.doi.org/10.3354/meps210203

LOGAN, J.M., JARDINE, T.D., MILLER, T.J., BUNN, S.E., CUNJAK, R.A. \& LUTCAVAGE, M.E. 2008. Lipid corrections in carbon and nitrogen stable isotope analyses: comparison of chemical extraction and modelling methods. J. Anim. Ecol. 77:838-846. PMid:18489570. http://dx.doi. org $/ 10.1111 / \mathrm{j} .1365-2656.2008 .01394 . x$

MARTINS, A.S., HAIMOVICI, M. \& PALACIOS, R. 2005. Diet and feeding of the cutlassfish Trichiurus lepturus in the Subtropical Convergence Ecosystem of southern Brazil. J. Mar. Biol. Ass. U.K. 85:1223-1229. http://dx.doi.org/10.1017/S002531540501235X

NEWSOME, S.D., DEL RIO, C.M., BEARHOP, S. \& PHILLIPS D.L. 2007. A niche for isotopic ecology. Front. Ecol. Environ. 5:429-436.

OHIZUMI, H., KURAMOCHI, T., KUBODERA, T., YOSHIOKA, M. \& MIYAZAKI, N. 2003. Feeding habits of Dall's porpoises (Phocoenoides dalli) in the subarctic North Pacific and the Bering Sea basin and the impact of predation on mesopelagic micronekton. Deep-Sea Res. I 50:593610. http://dx.doi.org/10.1016/S0967-0637(03)00033-5

PETERSON, B.J. \& FRY, B. 1987. Stable isotopes in ecosystem studies. Annu. Rev. Ecol. Syst. 18:293-320. http://dx.doi.org/10.1146/annurev. es. 18.110187 .001453

PIMM, S.L. 2002. Food webs. 2nd ed. The University Chicago Press, Chicago. PMid:12468828.

POST, D.M., LAYMAN, C.A., ARRINGTON, D.A., TAKIMOTO, G., QUATTROCHI, J. \& MONTAÑA, C.G. 2007. Getting to the fat of the matter: models, methods and assumptions for dealing with lipids in stable isotope analyses. Oecologia 152:179-189. PMid:17225157. http:// dx.doi.org/10.1007/s00442-006-0630-x

RENAUD, P.E., TESSMANN, M., EVENSET, A. \& CHRISTENSEN, G.N. 2011. Benthic food web structure of an Artic fjord (Kongsfjorden, Svalbard). Mar. Biol. Res. 7:13-26. http://dx.doi.org/10.1080/17451001003671597

SWEETING, C.J., POLUNIN, N.V.C. \& JENNINGS, S. 2006. Effects of chemical lipid extraction and arithmetic lipid correction on stable isotope ratios of fish tissues. Rapid Commun. Mass Sp. 20:595-601. PMid:16429479. http://dx.doi.org/10.1002/rcm.2347

TIESZEN, L.L., BOUTTON, T.W., TESDAHL, K.G. \& SLADE, N.A. 1983. Fractionation and turn-over of stable carbon isotopes in animal tissues: implication for d13C analysis of diet. Oecologia 57:32-37. http://dx.doi. org/10.1007/BF00379558 